Article

\title{
Distribution of Polybrominated Diphenyl Ethers in Sewage Sludge, Sediments, and Fish from Latvia
}

\author{
Juris Aigars, Natalija Suhareva * and Rita Poikane \\ Latvian Institute of Aquatic Ecology, Voleru Street 4, Riga LV1007, Latvia; juris.aigars@lhei.lv (J.A.); \\ rita.poikane@lhei.lv (R.P.) \\ * Correspondence: natalija.suhareva@lhei.lv; Tel.: +371-2-601-7080
}

Academic Editor: Yu-Pin Lin

Received: 1 December 2016; Accepted: 1 February 2017; Published: 8 February 2017

\begin{abstract}
The polybrominated diphenyl ethers (PBDEs) are bioaccumulative, persistent, and toxic. They have a high risk of emission into the environment via volatile losses and diffuse sources, such as commercial product disposal or the use of sewage sludge. The PBDEs' congeners were analyzed in municipal waste water treatment plant (WWTP) sludge, river and lake water, sediment, and fish samples, to investigate the concentrations in urban and natural locations. The sum of eight PBDE congener $\left(\sum_{8} \mathrm{PBDE} 28,47,99,100,153,154,183,209\right)$ concentrations in WWTP sludge varied from $78 \mathrm{ng} \cdot \mathrm{g}^{-1} \mathrm{DW}$, to $714 \mathrm{ng} \cdot \mathrm{g}^{-1} \mathrm{DW}$. The BDE 209 constituted up to $93 \%-98 \%$ of $\sum_{8} \mathrm{PBDE}$. In water, the concentrations of all of the measured PBDE congeners were below the limit of detection. Similarly, the concentration of BDE 209 in the sediments was below the limit of detection in all samples. The sum of seven PBDE congener concentrations in the sediments varied from 0.01 to $0.13 \mathrm{ng} \cdot \mathrm{g}^{-1} \mathrm{DW}$. The sum of eight PBDE congener concentrations in fish (European perch) tissues varied from 0.13 to $0.82 \mathrm{ng} \cdot \mathrm{g}^{-1} \mathrm{WW}$. As was recorded for the WWTP sludge, the BDE 209 was the dominant congener, constituting $24 \%-93 \%$ of $\sum_{8} \mathrm{PBDE}$. The sum of seven PBDE congener concentrations, excluding BDE 209, as well as the concentrations of BDE 209 that were measured in WWTP sludge, exhibited a weak negative correlation (Pearson's $r=-0.56, p=0.1509$ and $r=-0.48, p=0.2256$, respectively) with the content of dry matter in the sludge. The sum of seven PBDE congener concentrations measured in sediments exhibited a strong negative correlation (Pearson's $r=-0.82, p=0.0006$ ) with the content of dry matter in the sediments, and a strong positive correlation (Pearson's $r=0.68, p=0.0109$ ) with the total carbon content. The obtained results indicated that the fine-grained WWTP sludge particles, with a larger relative surface area, adsorbed BDE 209 the most effectively. This finding was supported by the relatively low environmental concentrations of PBDE congeners, especially BDE 209 , which can be explained by the lack of using sewage sludge in agricultural application in Latvia. Furthermore, it seems that, at present, the observed differences in the PBDE congener concentrations in sediments can be attributed to differences in the physical-chemical properties of sediments.
\end{abstract}

Keywords: PBDEs; sewage sludge; sediments; fish; distribution

\section{Introduction}

The polybrominated diphenyl ethers (PBDEs) are halogenated compounds, which were listed as persistent organic pollutants (POPs) by the Stockholm Convention in 2009 [1]. The lipophilic, bioaccumulative, and toxic nature of these compounds [2], combined with the diversity of sources and transport mechanisms [3,4], have been causing significant public concern during the last decades. Three commercial mixtures (penta-, octa-, and deca-BDE), introduced in the 1970s, have been widely used as additive flame retardants in various industrial applications, such as plastics, textiles, electronics, building materials, furniture, and other products for manufacturing $[3,5,6]$. However, they have a high risk of emission into the environment [7]. Due to volatile losses and discharges during 
the constant use and recycling of the products containing these compounds, the diffuse sources of PBDEs, represented by commercial product disposal, the use of sewage sludge, agricultural run-off, and domestic wastewater [8,9], become even more significant than the point sources [10], imposing an additional environmental concern.

The first recorded detection of the presence of PBDEs in the environment was published by Andersson and Blomqvist, in 1981 [11]. Since then, PBDEs have been found in various environmental and biological samples across the globe [4,12-15]. Notably, the contamination of PBDEs was even reported in places with no local point source or industrial production $[16,17]$. PBDEs tightly bind to solid particles due to their properties [14], however, they can be transferred to the air due to volatilization [10], and transported over large distances. In the environment, PBDEs are transferred to aquatic systems, accumulated in sediments and biota [3,10,13], and are eventually biomagnified in top predators [18-20], to the point at which they can be transferred to humans through the consumption of contaminated food sources [2]. The transport mechanism described above is supported by environmental studies, which report on the increased levels of tetra- to deca-BDE isomers found in marine mammals, bird eggs, and human tissues [5,14]. According to several recent studies, the toxic effect caused by PBDEs can be observed as suppression of the immune system, reproductive dysfunction, endocrine disruption, change of thyroid hormone levels [5,8,21-23], damage of liver and kidney morphology, and fetal toxicity/teratogenicity cases [24-29]. Due to the toxicological effects, the production of PBDE congeners (penta- and octa-BDE) and their commercial availability were banned in the European Union [30-32]. These restrictions promoted a general decrease of PBDE concentrations in soils within Europe [33]. In addition, a decline of penta- and octa-mix PBDE concentrations has been observed in sewage sludge during recent years [34]. At the same time, concentrations of BDE 209 in sewage sludge, have exhibited a clear increase between 2004 and 2010 [34]. This fact poses a serious environmental concern, since current evidence suggests that some aquatic organisms, including fish, have a capacity to de-brominate BDE 209 to lower-brominated congeners [35,36], which have higher mobility and toxicological properties. Furthermore, it has been demonstrated that benthic fauna is able to re-mobilize buried PBDEs from sediments [37], and consequently, sediments become an important secondary source of these compounds.

The aim of this study was to evaluate the concentration levels and composition of PBDE congeners in the water, fish tissues, and sediments, as well as in the sludge collected from different WWTPs in Latvia.

\section{Materials and Methods}

Sewage sludge samples from effluent, after the dewatering step, were collected from eight urban WWTPs (Table 1), located in the biggest cities and smaller towns of Latvia. The WWTPs were selected based on a range of city sizes and the type of effluents treated by WWTPs.

Table 1. General information on city-size, waste water type, and the amount treated by WWTP.

\begin{tabular}{llll}
\hline WWTP & $\begin{array}{l}\text { Population, } \\
\text { Inhabitants }\end{array}$ & $\begin{array}{l}\text { Treatment, } \\
\mathbf{m}^{3} / \text { Day }\end{array}$ & Waste Water Type \\
\hline Riga WWTP & 696,593 & 350,000 & Municipal and industrial waste water \\
\hline Daugavpils WWTP & 96,028 & 12,600 & Municipal and manufacturing waste water, rain water \\
\hline Liepaja WWTP & 78,413 & 18,400 & $\begin{array}{l}\text { Municipal waste water, manufacturing and industrial } \\
\text { waste water }\end{array}$ \\
\hline Ventspils WWTP & 40,057 & 19,200 & Municipal and manufacturing waste water \\
\hline Rezekne WWTP & 31,591 & 5600 & $\begin{array}{l}\text { Municipal waste water and bio-toilets, manufacturing } \\
\text { and industrial waste water }\end{array}$ \\
\hline Valmiera WWTP & 25,318 & 5000 & Municipal waste water \\
\hline Saldus WWTP & 11,625 & 2900 & Municipal waste water only \\
\hline Dobele WWTP & 10,231 & 3500 & Industrial and municipal waste water \\
\hline
\end{tabular}


The water and sediment samples were collected from sampling locations of five rivers and eight lakes (Table 2). Samples of fish dorsal muscles were collected from the same sampling sites as the sediment samples (Table 2), however, the biomass was only sufficient for analysis purposesin 10 cases out of the 13 sampled biota European perch (Perca fluviatilis),. The selection of the sampling sites was based on previously reported cases of trans-boundary impact, and the human influence on urban, agricultural, or industrial land use location. The selection of European perch (Perca fluviatilis) for the biota matrix was based on its trophic level (predator), and the high abundance of the species occurring in both fresh and brackish waters of the region.

Table 2. Description of the investigated water bodies and sediment characteristics.

\begin{tabular}{|c|c|c|c|c|c|c|c|c|}
\hline \multirow{2}{*}{$\begin{array}{l}\text { Name } \\
\text { Salaca }\end{array}$} & \multirow{2}{*}{$\begin{array}{l}\text { Type } \\
\text { river }\end{array}$} & \multirow{2}{*}{$\begin{array}{c}\begin{array}{c}\text { Coordinates } \\
\text { WGS84 }\end{array} \\
57.756183 \\
24.351069 \\
\end{array}$} & \multirow{2}{*}{$\begin{array}{c}\begin{array}{c}\text { Mean } \\
\text { Depth, m }\end{array} \\
0.15\end{array}$} & \multirow{2}{*}{$\begin{array}{c}\begin{array}{c}\text { Length, } \\
\text { km }\end{array} \\
95\end{array}$} & \multirow{2}{*}{$\begin{array}{c}\begin{array}{c}\text { Surface } \\
\text { Area, ha }\end{array} \\
\text { NA }\end{array}$} & \multirow{2}{*}{$\begin{array}{c}\begin{array}{c}\text { Biota } \\
\text { Sampled }\end{array} \\
\text { Yes }\end{array}$} & \multicolumn{2}{|c|}{$\begin{array}{c}\text { Sediments } \\
\text { DM (\%) OC (\%) }\end{array}$} \\
\hline & & & & & & & 61.1 & 1.88 \\
\hline Mazsalaca & river & $\begin{array}{l}57.857745 \\
25.051484\end{array}$ & 0.15 & 95 & NA & Yes & 80.0 & 0.17 \\
\hline Pedele & river & $\begin{array}{l}57.778913 \\
26.024400\end{array}$ & 0.3 & 31 & NA & No & 81.3 & 0.16 \\
\hline Gauja & river & $\begin{array}{l}57.160162, \\
24.265724\end{array}$ & 2.0 & 452 & NA & Yes & 68.0 & 0.47 \\
\hline Abuls & river & $\begin{array}{l}57.549172, \\
25.680512\end{array}$ & 0.4 & 52 & NA & No & 58.9 & 1.92 \\
\hline Dūņezers & lake & $\begin{array}{l}57.150275 \\
24.358443\end{array}$ & 1.1 & NA & 145.6 & Yes & 17.6 & 18.9 \\
\hline Burtnieks & lake & $\begin{array}{l}57.740413 \\
25.241186\end{array}$ & 2.9 & NA & 4006.0 & Yes & 14.0 & 10.5 \\
\hline Murāts & lake & $\begin{array}{l}57.575807 \\
27.085749\end{array}$ & 2.2 & NA & 77.5 & Yes & 15,2 & 14.7 \\
\hline Juveris & lake & $\begin{array}{l}57.218670 \\
25.676606\end{array}$ & 8.5 & NA & 77.5 & Yes & 16.4 & 11.2 \\
\hline Lizdoles & lake & $\begin{array}{l}57.293444, \\
25.838392\end{array}$ & 4.4 & NA & 53.9 & Yes & 8.8 & 15.7 \\
\hline Trikātas & lake & $\begin{array}{l}57.541006 \\
25.714902\end{array}$ & 1.8 & NA & 13.0 & Yes & 8.1 & 10.5 \\
\hline Alauksts & lake & $\begin{array}{l}57.091547, \\
25.774342\end{array}$ & 3.3 & NA & 774.8 & No & 7.0 & 16.4 \\
\hline Limbažu & lake & $\begin{array}{l}57.486541 \\
24.699041\end{array}$ & 3.8 & NA & 24.8 & Yes & 47.2 & 15.4 \\
\hline
\end{tabular}

NA: not applicable.

\subsection{Sample Collection}

The sewage sludge, water, and sediment samples were placed and kept in previously unused amber-glass sample containers, precleaned and Certified to meet US EPA performance-based specification.

The integrated $(1 \mathrm{~h})$ sewage sludge samples were collected between June 2010 and February 2011 by the WWTP operational staff in $500 \mathrm{~mL}$ containers, and were covered by polytetrafluoroethylene-lined (PTFE) plastic screw-caps. To avoid the adsorption of PBDEs at the PTFE parts of the screw-cap, the container neck was kept isolated by aluminum folium.

The water and sediment samples were collected between the July and September of 2012. Water was sampled by a Van Dorn water sampler $0.3-0.5 \mathrm{~m}$ below the water surface, and immediately upon sampling, the water was transferred to prepared glass jars. Sediment samples were collected with a hand-operated Wildco Ponar or VanVeen bottom grab sampler. Sampling was performed at five to seven points around the observation site. All sub-samples were mixed together and sieved, 
to remove particles larger than $2.0 \mathrm{~mm}$. Sieved sediment samples were then transferred to prepared glass jars.

European perch (Perca fluviatilis) individuals were sampled by means of fish hooks. Sampling was performed by dully authorized personnel, possessing valid fishing permits. Thereafter, the fish tissues were obtained for analysis, in accordance with animal ethic care guidelines. Every sample collected during the study was directly transported from the sampling site to the laboratory, in a mobile cool box filled with cooling agent cartridges.

The obtained sewage sludge, water, and sediment samples were stored in dark conditions, at a temperature of $4-8{ }^{\circ} \mathrm{C}$, until the chemical analysis had been performed. The soft tissues obtained from the fish were stored in a freezer at a temperature of $-18^{\circ} \mathrm{C}$, until the chemical analysis had been carried out.

\subsection{Analytical Procedures}

The pretreatment and analyses of all types of the samples were performed according to the method US EPA 1614, with modification. Water and sewage sludge samples were analyzed by the accredited commercial laboratory, ALS Laboratory Group (Czech Republic), with the estimation of uncertainty for each PBDE congener being equal to 30\%. Sediments and fish samples were treated on a commercial basis by the Institute of Food Safety, Animal Health, and Environment-"BIOR" (Latvia), and the recovery range for the PBDEs was $75 \%-123 \%$. The method of determining the PBDEs in the required matrices was accredited for both engaged laboratories. The limits of quantification were defined on the basis of the blank level (see Supplementary Materials).

\subsubsection{Sample Preparation and Clean-Up for PBDEs Analysis}

Sample aliquots of sediment (10 $\pm 2 \mathrm{~g})$ and the fresh dorsal muscle of fish (10 $\pm 2 \mathrm{~g})$, were spiked with $500 \mu \mathrm{L}$ of ${ }^{13} \mathrm{C}_{12}$-labeled PBDE 138 congener mixture solution, diluted with toluene to a final concentration of $1-5 \mathrm{pg} \cdot \mu \mathrm{L}^{-1}$, before being mixed with $100 \mathrm{~g}$ of anhydrous sodium sulfate. After equilibration for $12 \mathrm{~h}$, at UV-protected conditions, e.g., room temperature under an aluminum foil cover, the samples were ground and extracted, using Soxhlet extraction with a dichloromethane $/ n$-hexane $(1: 1, v / v)$ mixture for at least $16 \mathrm{~h}$. The extracts were filled into round-bottom flasks and the solvent was removed using a rotary evaporator at $<30{ }^{\circ} \mathrm{C}$. The high molecular substances were removed by gel permeation chromatography (GPC). The system was equipped with a glass column $(50 \times 2.5 \mathrm{~cm})$, filled with $50 \mathrm{~g}$ of non-polar divinyl-benzene/styrene copolymer Bio-Beads S-X3 (Bio-Rad, Philadelphia, PA, USA, 3\% cross linkage, 40-80 $\mu \mathrm{m}$ bead size, $\leq 2000 \mathrm{MW}$ limit) stationary phase, and eluted with cyclohexane/ethyl acetate $(1: 1, v / v)$ mobile phase, at a flow rate of $5 \mathrm{~mL} \cdot \mathrm{min}^{-1}$. The automated GPC program was as follows: dump time 0-19 min, collection time 19-45 min; the collected eluate was concentrated by rotary evaporation at $<30^{\circ} \mathrm{C}$. The pre-purified sample extract was placed on top of a glass column $(25 \times 1.2 \mathrm{~cm})$ filled with $2.5 \mathrm{~g}$ of silica gel, containing $50 \%(v / v)$ sulfuric acid for the degradation of remaining lipids. The analytes were eluted with $1.0 \mathrm{~mL}$ of toluene, and subsequently, with $25 \mathrm{~mL}$ of $n$-hexane. After rotary evaporation to about 150-200 $\mu \mathrm{L}$, the sample extracts were transferred to $2 \mathrm{~mL}$ chromatographic vials, treated with $37 \mathrm{~N}$ sulfuric acid $(30 \mu \mathrm{L})$, and mixed. The mixture was allowed to stand for $20 \mathrm{~min}$, before being centrifuged at $3000 \mathrm{rpm}$ (1508 RCF), in order to separate the acidic and organic layers. The acidic bottom layer was discarded, the organic layer was evaporated, and recovery standard $\left({ }^{13} \mathrm{C}_{12}\right.$ PBDE 138$)$ solution in $n$-nonane was added until the solution was $50 \mu \mathrm{L}$, at which point content of PBDEs was analyzed [38].

\subsubsection{Instrumental Analysis and Quantification of PBDEs by GC-HRMS}

The instrumental analysis was performed by a Micromass Autospec Premier high resolution mass spectrometer (Milford, CT, USA), coupled with an Agilent $6890 \mathrm{~N}$ gas chromatograph (Santa Clara, CA, USA), according to the procedure and GC conditions described by Zacs, et al. [38]. 


\subsubsection{Analysis of Dry Matter Content, Total Carbon, and Lipid Content}

The dry-matter content of fish muscle, sediment, and sludge samples, was detected by a gravimetric method, during which separate wet subsamples were dried at $105 \pm 5{ }^{\circ} \mathrm{C}$ until a constant dry weight was observed.

The total content of carbon in the sediments was determined according to the ISO method 10694:1995, "Soil quality-Determination of organic and total carbon after dry combustion (elementary analysis)". A $2 \mathrm{mg}$ DW sub-sample was used to measure the total content of carbon, and was recorded by a Vario EL III CHNOS Elemental Analyzer (Elementar Analysensysteme GmbH, Langenselbold, Germany).

A $20 \mathrm{~g}$ DW sub-sample was used in Soxhlet extraction with a dichloromethane and n-hexane $(1: 1, v / v)$ mixture, in order to determine the lipid content. The extraction time was $16 \mathrm{~h}$, after which the extracts were filled into pre-weighted round-bottom flasks for solvent evaporation, by a rotary evaporator at $<30^{\circ} \mathrm{C}$. The lipid content was determined gravimetrically.

\subsection{Data Exploration and Statistical Assessment}

Data exploration and statistical analyses were performed using R software for Windows, Release 3.3.2. The strength of the linear associations between the measured PBDE concentrations, content of dry matter (DM) in sewage sludge, content of dry material (DW), total organic carbon (TOC) in sediments, and content of lipids in fish samples, was investigated by means of the Pearson Correlation Coefficient, with a statistical significance level set at $\alpha=0.05$. Simple regression models with a single independent parameter were developed, to evaluate the dependence of the concentration of BDE 209 on the content of dry matter in sewage sludge, and the variations in the PBDEs concentrations, depending on the content of dry matter and the total organic carbon in sediment samples. The obtained regression models were evaluated via regression diagnostic tools, including graphical methods and formal statistical tests.

\section{Results}

\subsection{WWTP Sludge}

The concentrations of PBDE congeners (BDE 28, 47, 99, 100, 153, 154, 183, 209) in WWTPs sludge ranged from $0.1 \mathrm{ng} \cdot \mathrm{g}^{-1} \mathrm{DW}$ (BDE 28) to $700 \mathrm{ng} \cdot \mathrm{g}^{-1} \mathrm{DW}$ (BDE 209). Both values were observed at the Valmiera WWTP (Figure 1$)$. The sum of all of the detected congeners $\left(\sum_{8} \mathrm{PBDE}\right)$ varied substantially among WWTPs, from $78 \mathrm{ng} \cdot \mathrm{g}^{-1} \mathrm{DW}$ at the Liepaja WWTP, to $714 \mathrm{ng} \cdot \mathrm{g}^{-1} \mathrm{DW}$ at the Valmiera WWTP. The concentrations of PBDEs in the sewage sludge reported in this study, are at the low end of the wide concentration range reported elsewhere for WWTPs' sludge $[6,39,40]$, and similar to the earlier studies, the concentrations of BDE 209 (on average $296 \mathrm{ng} \cdot \mathrm{g}^{-1} \mathrm{DW}$ ) constituted $89 \%-98 \%$ of the $\sum_{8} \mathrm{PBDE}$ concentration registered. The second (BDE 99) and third (BDE 47) most abundant PBDE congeners corresponded to only $0.8 \%-4.9 \%$ and $0.7 \%-4.4 \%$ of the $\sum_{8} \mathrm{PBDE}$, respectively, while the remaining congeners constituted less than $1 \%$ of the $\sum_{8} \mathrm{PBDE}$.

The average concentration of the PBDEs, excluding BDE 209, ( $\left.\sum_{7} \mathrm{PBDE}\right)$ was $13 \mathrm{ng} \cdot \mathrm{g}^{-1} \mathrm{DW}$. The $\sum_{7} \mathrm{PBDE}$, as well as BDE 209, exhibited a weak negative correlation (Pearson's $r=-0.56, p=0.1509$ and $r=-0.48, p=0.2256$, respectively) with the dry-matter content of WWTP sludge (Table 3). The correlation between BDE 209 and the dry-matter content of WWTP sludge is substantially improved (Pearson's $r=-0.98, p=0.0008$ ) if the data from two WWTPs, Saldus and Rezekne, are not included in the analysis (Table 3). The decision to exclude the outlying observations was based on the statistical diagnosis of linear regression (Figure 2), and a comparison of the significance levels of the accessed interactions ( $p$-value $=0.2256$ for initial model versus $p$-value $=8.018 \times 10^{-4}$ for the ameliorated model). At the same time, BDE 209 concentration did not exhibit significant correlation with concentrations of other congeners (Table 3). 
- BDE $28 \square$ BDE $99 \square$ BDE 153 므 183

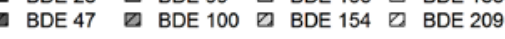

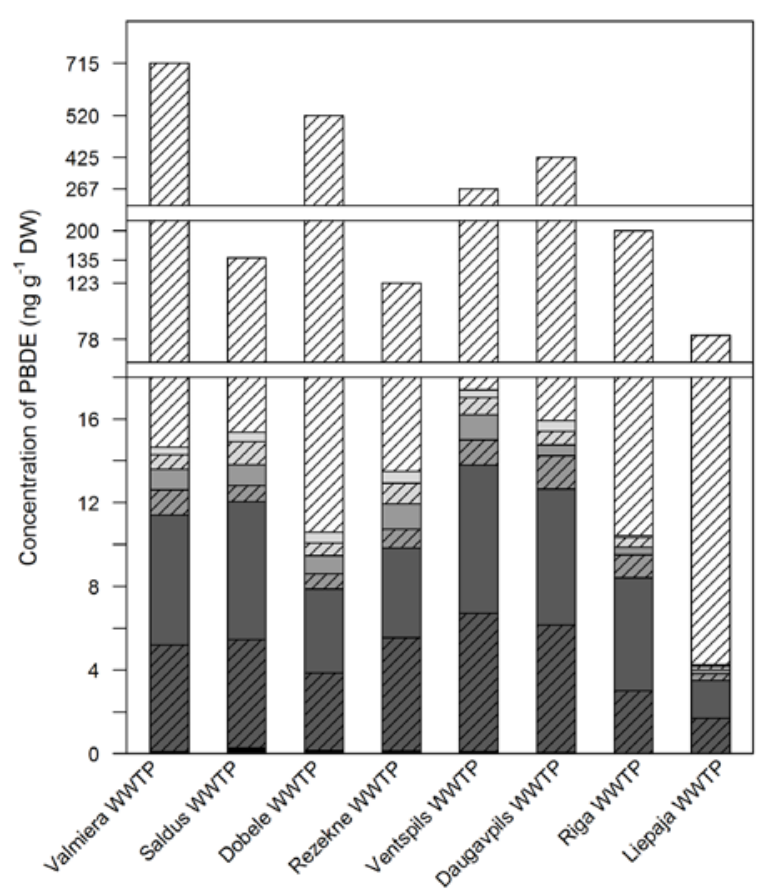

Figure 1. Concentrations of PBDEs in sewage sludge from eight urban WWTPs in Latvia.

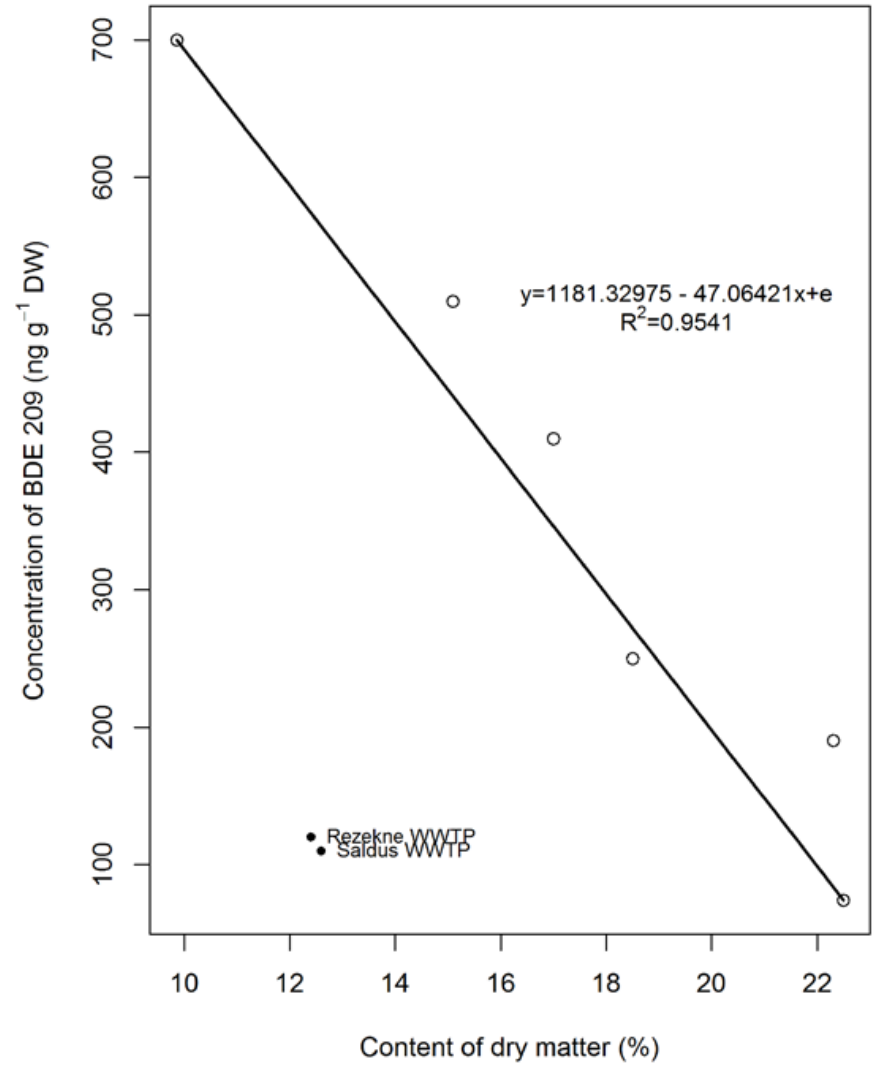

Figure 2. Linear regression curve of BDE 209 concentrations with the sewage sludge content of dry matter. 
Table 3. Pearson correlation coefficients and $p$-values calculated for PBDE concentrations and the content of dry matter analyzed in sewage sludge samples.

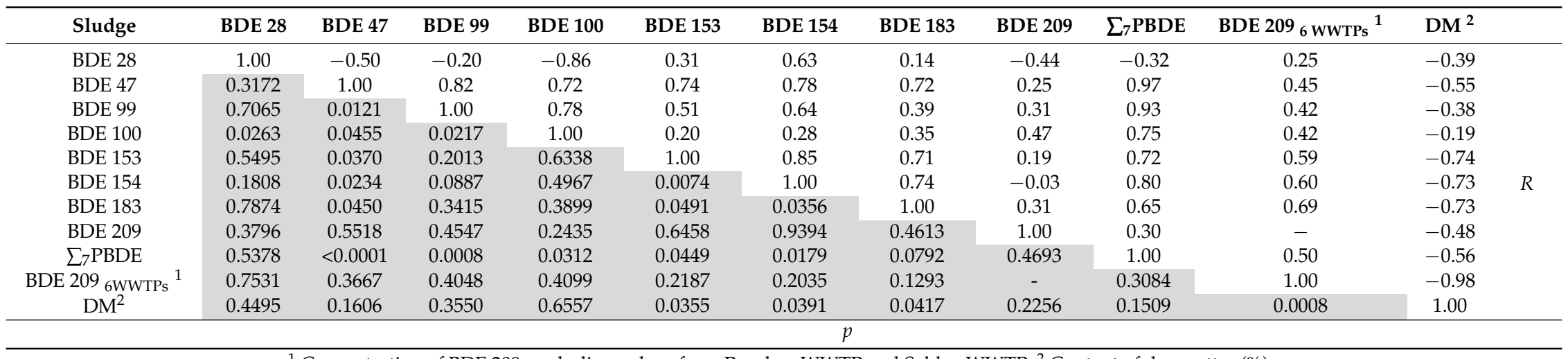

${ }^{1}$ Concentration of BDE 209, excluding values from Rezekne WWTP and Saldus WWTP; ${ }^{2}$ Content of dry matter (\%). 


\subsection{Water and Sediments}

The concentrations of all measured PBDE congeners, in all of the water samples, were between the limit of detection (LOD) and the limit of quantification (LOQ). The LOD and LOQ of congeners (BDE 28, 47, 99, 100, 153 and 154), for which the sum of the Ecological Quality Standard (EQS) (140 ng. $\mathrm{L}^{-1}$ ) is set in Directive 2013/39/EU for inland surface waters, varied in the samples, between 0.8 and $1.1 \mathrm{ng} \cdot \mathrm{L}^{-1}$ for LOD, and 1.7 and $2.3 \mathrm{ng} \cdot \mathrm{L}^{-1}$ for LOQ. For these congeners, it is possible to use LOD values to calculate the assumed maximal concentration of $2.3 \mathrm{ng} \cdot \mathrm{L}^{-1}$. This estimated concentration is below the EQS that is set in Directive 2013/39/EU. The congeners BDE 183 and 209 are not included in the group of priority PBDEs, for which the EQS is set. However, it is reasonable to evaluate their concentrations in water due to the ability of biological organisms to de-brominate them to lower-brominated congeners. Since the possible concentrations of BDE 183 (below LOQ $0.38 \mathrm{ng} \cdot \mathrm{L}^{-1}$ ) and BDE 209 (below LOQ $2.70 \mathrm{ng} \cdot \mathrm{L}^{-1}$ ) could also be considered as very low, it can be safe to assume that the set EQS would not be exceeded, even if all of the BDE 183 and 209 would be de-brominated.

The concentrations of BDE 209 in sediments were below LOD $\left(0.2 \mathrm{ng} \cdot \mathrm{g}^{-1} \mathrm{DW}\right)$ in all samples. The concentrations of other PBDE congeners in sediment samples (Figure 3) varied significantly, from $1.3 \times 10^{-4} \mathrm{ng} \cdot \mathrm{g}^{-1} \mathrm{DW}$ for BDE 28 in the sediments of river Pedele, to $0.052 \mathrm{ng} \cdot \mathrm{g}^{-1} \mathrm{DW}$ for BDE $47 \mathrm{in}$ the sediments of lake Trikata. Similarly, as is the case for WWTP sludge, the levels of PBDE congeners and the $\sum_{7} \mathrm{PBDE}$ (range $0.01-0.13 \mathrm{ng} \cdot \mathrm{g}^{-1} \mathrm{DW}$, on average $0.05 \mathrm{ng} \cdot \mathrm{g}^{-1} \mathrm{DW}$ ) detected in the sediments, were on the low end of the range of values observed elsewhere $[10,41,42]$.

The $\sum_{7} \mathrm{PBDE}$ exhibited non-linear relations (Figure 4) and a significant (Pearson's $r=-0.82$, $p=0.0006$ ) negative correlation with the content of dry matter, and a positive (Pearson's $r=0.68$, $p=0.0107)$ nonlinear correlation with the total content of carbon in the sediments (Table 4).

- BDE $28 \square$ BDE $99 \square$ BDE $153 \square$ BDE 183 BDE $47 \square$ BDE $100 \square$ BDE 154

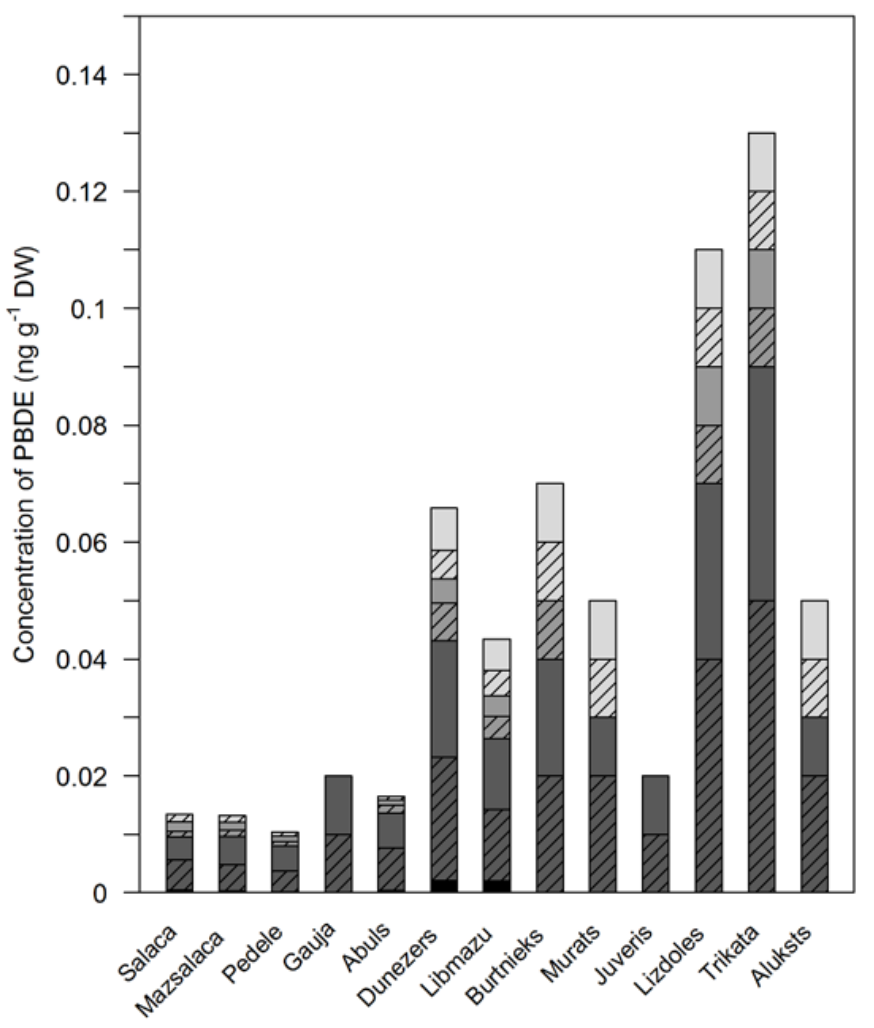

Figure 3. Concentrations of PBDEs in sediments from rivers and lakes in Latvia. 
Table 4. Pearson correlation coefficients and $p$-values calculated for PBDE concentrations, the content of dry material, and the total organic carbon analyzed in sediment samples.

\begin{tabular}{|c|c|c|c|c|c|c|c|c|c|c|c|}
\hline Sediments & BDE 28 & BDE 47 & BDE 99 & BDE 100 & BDE 153 & BDE 154 & BDE 183 & $\mathrm{DW}^{1}$ & $\sum_{7} \mathrm{PBDE}$ & TOC $^{2}$ & \\
\hline BDE 28 & 1.00 & -0.15 & -0.04 & 0.10 & 0.12 & -0.16 & -0.01 & 0.07 & -0.07 & 0.36 & \multirow{10}{*}{$R$} \\
\hline BDE 47 & 0.6352 & 1.00 & 0.96 & 0.77 & 0.82 & 0.78 & 0.79 & -0.74 & 0.98 & 0.57 & \\
\hline BDE 99 & 0.9065 & $<0.0001$ & 1.00 & 0.88 & 0.84 & 0.67 & 0.70 & -0.67 & 0.94 & 0.51 & \\
\hline BDE 100 & 0.7358 & 0.0021 & $<0.0001$ & 1.00 & 0.75 & 0.61 & 0.63 & -0.52 & 0.77 & 0.42 & \\
\hline BDE 153 & 0.6871 & 0.0006 & 0.0003 & 0.0034 & 1.00 & 0.43 & 0.44 & -0.37 & 0.78 & 0.34 & \\
\hline BDE 154 & 0.6048 & 0.0015 & 0.0128 & 0.0274 & 0.1440 & 1.00 & 0.98 & -0.80 & 0.83 & 0.70 & \\
\hline BDE 183 & 0.9677 & 0.0013 & 0.0083 & 0.0201 & 0.1279 & $<0.0001$ & 1.00 & -0.84 & 0.85 & 0.80 & \\
\hline $\mathrm{DW}^{1}$ & 0.8080 & 0.0036 & 0.0122 & 0.0682 & 0.2174 & 0.0011 & 0.0004 & 1.00 & -0.82 & -0.86 & \\
\hline$\sum_{7} \mathrm{PBDE}$ & 0.8104 & $<0.0001$ & $<0.0001$ & 0.0022 & 0.0017 & 0.0005 & 0.0003 & 0.0006 & 1.00 & 0.68 & \\
\hline TOC $^{2}$ & 0.2335 & 0.0426 & 0.0778 & 0.1580 & 0.2519 & 0.0077 & 0.0011 & 0.0002 & 0.0107 & 1.00 & \\
\hline \multicolumn{12}{|c|}{$n$} \\
\hline
\end{tabular}

${ }^{1}$ Content of dry material $(\%) ;{ }^{2}$ Content of total organic carbon $(\%)$. 


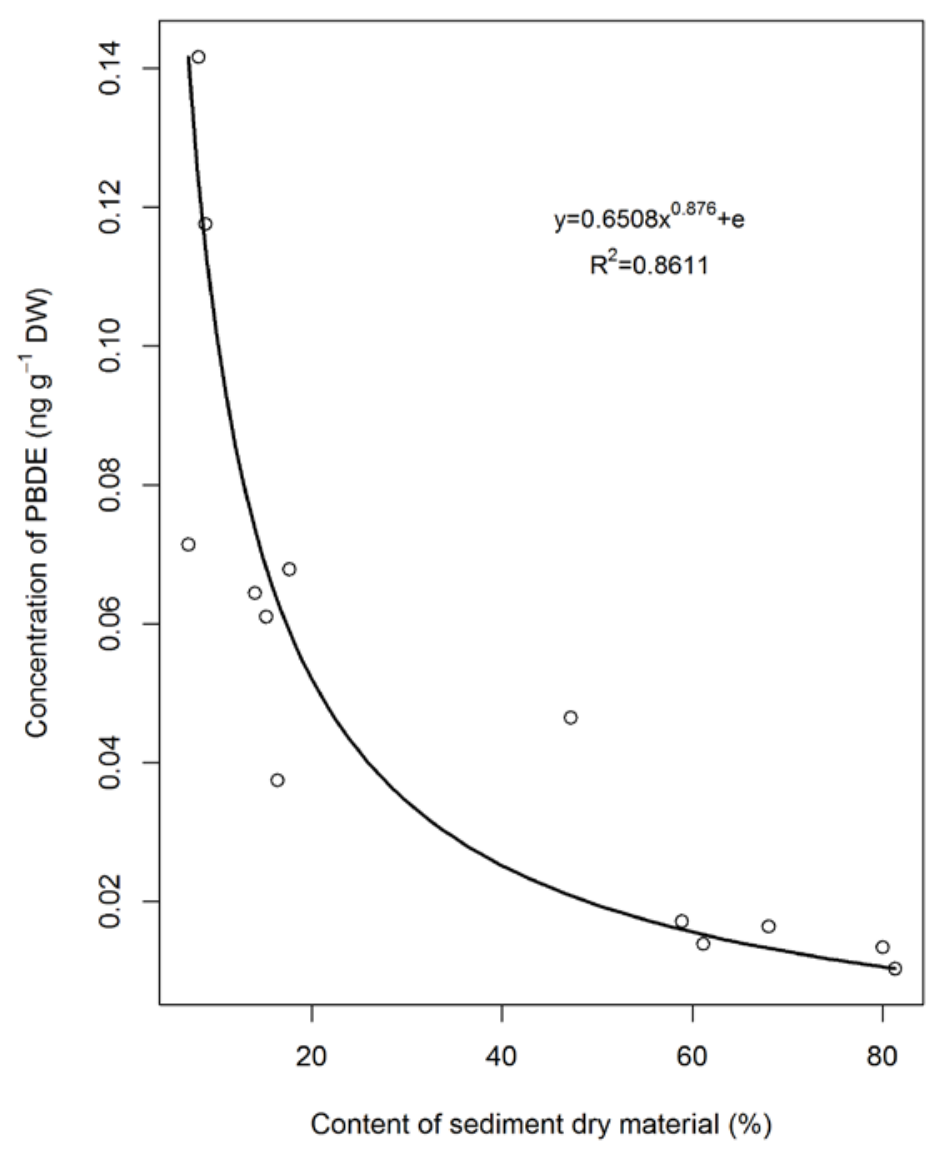

Figure 4. Non-linear regression showing dependency of $\sum_{7} \mathrm{PBDE}$ concentration from the sediment content of dry matter in lakes and rivers of Latvia.

\subsection{Fish}

The PBDE congener concentration range (Figure 5) in analyzed fish tissues ranged from $3 \times 10^{-4} \mathrm{ng} \cdot \mathrm{g}^{-1} \mathrm{WW}$ (BDE 28 in lake Murats), to $0.36 \mathrm{ng} \cdot \mathrm{g}^{-1} \mathrm{WW}$ (BDE 209 in lake Trikata). Similar to sewage sludge, BDE 209 was a dominant congener, constituting $24 \%-93 \%$ ( $53 \%$ on average) of the $\sum \mathrm{PBDE}_{8}$.

The concentrations of BDE 47, BDE 99, BDE 100, BDE 153, and BDE 154, constituted $18.6 \%, 7 \%$, $4.9 \%, 1.5 \%$, and $3.2 \%$, respectively, of the total, while other PBDE congeners represented less than $1 \%$ of the total amount. The accumulation of BDE 209 in the fish tissues observed in this study, is consistent with previous observations $[43,44]$. It is important to note that the sum of the concentrations of the congener numbers $28,47,99,100,153$, and 154 (range from 0.017 to $0.624 \mathrm{ng} \cdot \mathrm{g}^{-1} \mathrm{WW}$ ), exceeded the EQS (0.0085 $\left.\mathrm{ng} \cdot \mathrm{g}^{-1} \mathrm{WW}\right)$ set for biota in Directive 2013/39/EU, in all of the rivers and lakes targeted by this study.

The majority of the investigated PBDE congeners demonstrated a good correlation among themselves, except for the concentrations of BDE 209 and BDE 183, which did not correlate to any of the other congeners (Table 5). The established lipophilic properties of PBDEs [2] have been previously used to explain the accumulation of PBDEs in fish tissues, corresponding to their lipid content [45]. However, in our study, only the concentrations of BDE 183 exhibited a medium-strong correlation (Table 5) with the lipid content of fish tissues (Pearson's $r=0.46, p=0.1803$ ). The lipid content of the fish tissues observed in this study was between $1.1 \%$ and $3.5 \%$. This is at the low end of the lipid content range presented in previous studies [44]. Therefore, we have to assume that, in our study area, factors other than the lipid content could also be important. For example, Bertelsen et al. [46] suggested that proteins and other non-lipid components have a large influence on the bioaccumulation of PBDEs, 
if the lipid content is low. However, since we did not measure proteins or other non-lipid parameters in our experiment, we have no observational data to support the conclusion on the importance of proteins, or other components, on the accumulation of PBDEs.

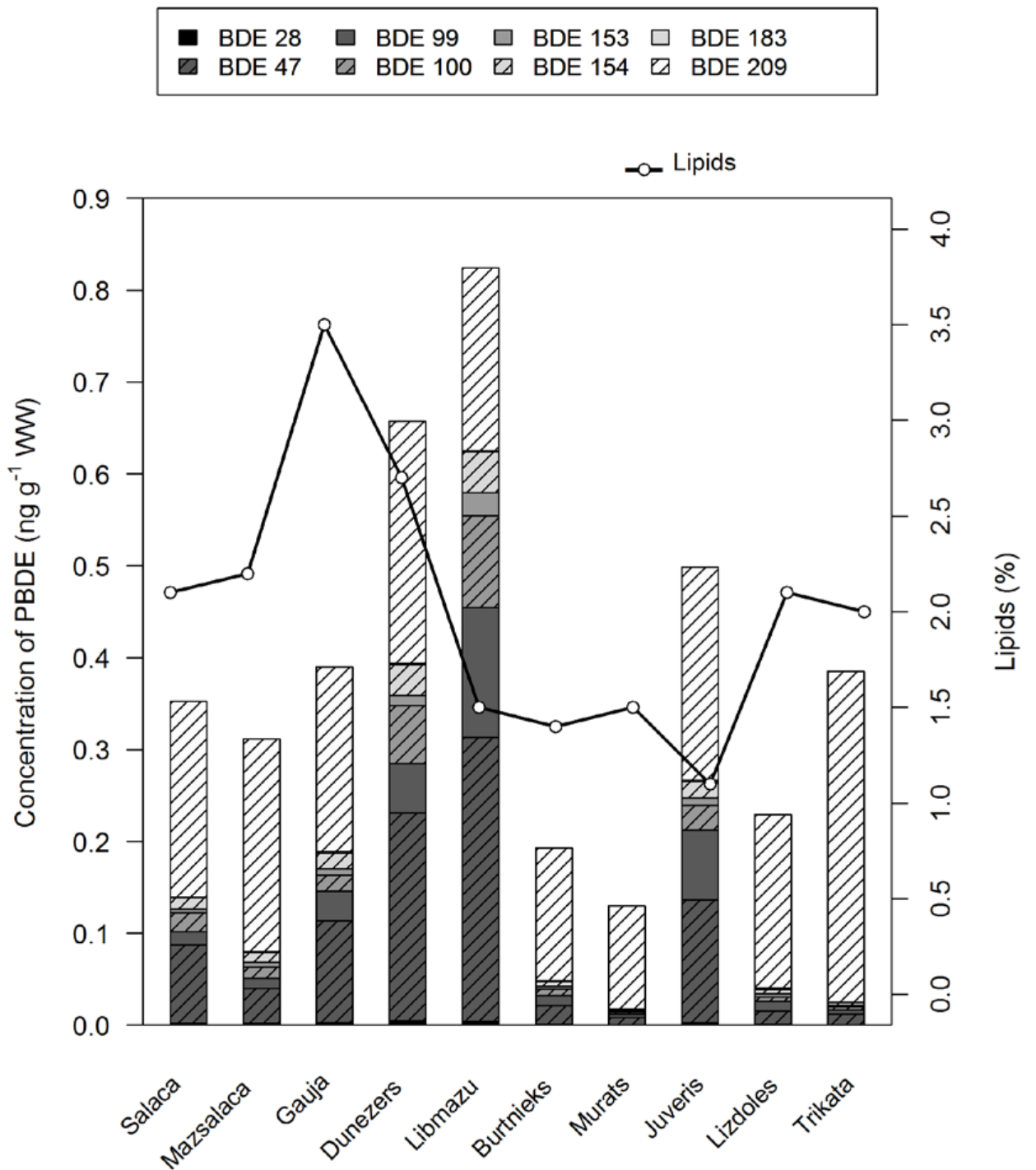

Figure 5. Concentrations of PBDEs and lipid content in tissues of European perch (Perca fluviatilis) from rivers and lakes of Latvia. 
Table 5. Pearson correlation coefficients and $p$-values calculated for PBDE concentrations and the content of lipids analyzed in tissues of European perch (Perca fluviatilis).

\begin{tabular}{|c|c|c|c|c|c|c|c|c|c|c|c|}
\hline Fish & BDE 28 & BDE 47 & BDE 99 & BDE 100 & BDE 153 & BDE 154 & BDE 183 & BDE 209 & $\sum_{7} \mathrm{PBDE}$ & Lipids (\%) & \\
\hline BDE 28 & 1.00 & 0.96 & 0.80 & 0.91 & 0.84 & 0.97 & 0.62 & 0.15 & 0.93 & 0.24 & \multirow{10}{*}{$R$} \\
\hline BDE 47 & $<0.0001$ & 1.00 & 0.92 & 0.98 & 0.94 & 0.99 & 0.52 & 0.11 & 0.99 & 0.06 & \\
\hline BDE 99 & 0.0060 & 0.0002 & 1.00 & 0.92 & 0.96 & 0.90 & 0.40 & 0.03 & 0.95 & -0.22 & \\
\hline BDE 100 & 0.0003 & $<0.0001$ & 0.0002 & 1.00 & 0.97 & 0.98 & 0.45 & 0.08 & 0.98 & -0.03 & \\
\hline BDE 153 & 0.0024 & $<0.0001$ & $<0.0001$ & $<0.0001$ & 1.00 & 0.95 & 0.44 & 0.02 & 0.97 & -0.09 & \\
\hline BDE 154 & $<0.0001$ & $<0.0001$ & 0.0003 & $<0.0001$ & $<0.0001$ & 1.00 & 0.55 & 0.11 & 0.99 & 0.10 & \\
\hline BDE 183 & 0.0574 & 0.1271 & 0.2558 & 0.1921 & 0.2017 & 0.0995 & 1.00 & 0.00 & 0.49 & 0.46 & \\
\hline BDE 209 & 0.6694 & 0.7670 & 0.9373 & 0.8186 & 0.9489 & 0.7712 & 0.9963 & 1.00 & 0.09 & 0.23 & \\
\hline$\sum_{7} \mathrm{PBDE}$ & 0.0001 & $<0.0001$ & $<0.0001$ & $<0.0001$ & $<0.0001$ & $<0.0001$ & 0.1497 & 0.8146 & 1.00 & -0.01 & \\
\hline Lipids (\%) & 0.4965 & 0.8612 & 0.5478 & 0.9336 & 0.8135 & 0.7747 & 0.1803 & 0.5147 & 0.9729 & 1.00 & \\
\hline
\end{tabular}




\section{Discussion}

The largest variations for a single congener in the WWTPs, were observed for BDE 209, as has also been observed in previous studies [6], while the levels of other congeners exhibited lower levels of variation. The observed variability in the BDE 209 levels could not be attributed to the city size, or the capacity of the WWTP, which is in agreement with conclusions from earlier studies [47]. At the same time, the approach for explaining the variance in BDE 209 levels, in relation to the different effluent types, e.g., industrial versus domestic [6], cannot be used in this study, since domestic sources of waste water dominated over industrial sources, in all cases. We cannot exclude that, in cities, such as Valmiera or Dobele, where comparatively high levels of BDE 209 in WWTP sludge were observed, the elevated BDE 209 input was generated by industrial objects. However, to the best of our knowledge, this is not the case. So, it is plausible to assume that the generation of the BDE 209 load per inhabitant, could be rather similar in all observed cities, but the capacity of WWTP to trap BDE 209, is different, depending on sludge properties. This assumption is supported by the observed negative correlation $(r=-0.48$, $p=0.2256$ ) between the content of dry matter and the BDE 209 concentration (Table 3), which clearly demonstrates that fine-grained sludge particles, with a larger relative surface area, adsorb BDE 209 much more effectively than relatively coarser-grained sludge particles (Figure 2). At the same time, it should be recognized that this correlation is built on a limited number of observation points, and two cases clearly diverge from the obtained linear regression curve (Figure 2). Therefore, prior to drawing a final conclusion, the factors that can possibly affect the effectiveness of BDE 209 retention in WWTP sludge, should be tested in a more detailed study.

It should be noted that the effectiveness of BDE 209 removal by WWTP sludge, poses a certain problem in relation to the widely practiced land-application of sludge in agriculture [6,47]. As has been previously shown, terrestrial plants can de-brominate BDE 209 to more mobile and toxic congeners [48,49]. Furthermore, substantial amounts of sludge applied to land are bound to enter aquatic environments, due to soil erosion. Although it can be expected that sludge particles will rapidly settle on the water basin floor, the ability of benthic animals to re-mobilize brominated flame retardants from sediments, can create a secondary pollution source [37]. Thereafter, the re-mobilized BDE 209 can be de-brominated by aquatic biota [35,36]. Since the fine-grained WWTP sludge, exhibiting a high capacity to accumulate BDE 209, would be best suited for land-application purposes, it is very likely that substantial amounts of BDE 209 might be introduced into the environment as a result of poorly evaluated WWTP sludge management actions.

The environmental concentrations of PBDE congeners observed in this study, especially BDE 209, are relatively low in comparison to previously reported values [10,41,42]. This can most likely be explained by the lack of using sewage sludge in agricultural applications in Latvia. Furthermore, it seems that, at present, the observed differences of PBDE congener concentrations in lake and river sediments, can be attributed to differences in sediment properties. For example, the sediments that have a low content of dry matter, and a relatively high content of organic carbon, exhibit substantially higher concentrations of PBDEs than those with a high content of sediment dry matter (Figure 4).

\section{Conclusions}

Although, relatively low environmental concentrations were indicated during the study, the risk of future concentration increase in the environment exists since WWTP sludge can be considered as a resource of monetary benefit and due to continuous investments in WWTP sector there is steady growing pressure on WWTP sludge utilization capacity. Therefore, it is necessary to invest particular attention to WWTP sludge utilization management practices and if necessary to modify them basing recommendations on further more detailed study about sewage sludge retention properties and affecting factors.

Supplementary Materials: The following are available online at www.mdpi.com/2076-3298/4/1/12/s1, Table S1: Concentrations of PBDEs (ng. $\mathrm{g}^{-1}$ ) and content of dry matter (DM) in sewage sludge, Table S2: Concentrations 
of PBDEs (ng. $\mathrm{g}^{-1}$ ), content of dry material (DW) and total organic carbon (TOC) in sediments, Table S3: Concentrations of PBDEs (ng. $\mathrm{g}^{-1}$ ) and content of lipids in tissues of European perch (Perca fluviatilis), Table S4: Limits of detection of PBDE concentration in water samples.

Acknowledgments: The study was supported by LIFE+ project "Baltic Actions for the reduction of Pollution of the Baltic Sea from Priority Hazardous Substances" (Project nr. LIFE07 ENV EE 000122) and Estonia-Latvia program project "Towards joint management of the transboundary Gauja/Koiva river basin district" (EU 38839).

Author Contributions: Juris Aigars analyzed the data. Juris Aigars and Natalija Suhareva were involved in writing the paper. Rita Poikane designed the experiments, performed the sampling campaign, and was involved in sample pretreatment and data interpretation.

Conflicts of Interest: The authors declare no conflict of interest.

\section{References}

1. EU. Stockholm Convention on Persistent Organic Pollutants. Adoption of Amendments to Annexes A, B, and C. UNEP/POPS/COP/SC-4/13. 2009. Available online: chm.pops.int/Portals/0/download.aspx?d= UNEP-POPS-COP.4-SC-4-13.English.pdf (accessed on 1 December 2016).

2. Jones, K.C.; de Voogt, P. Persistent organic pollutants (POPs): State of the science. Environ. Pollut. 1999, 100, 209-221. [CrossRef]

3. Ssebugere, P.; Sillanpaa, M.; Wang, P.; Li, Y.; Kiremire, B.T.; Kasozi, G.N.; Zhu, C.; Ren, D.; Shang, H.; Zhang, Q.; et al. Polychlorinated dibenzo-p-dioxins, polychlorinated dibenzofurans and polybrominated diphenyl ethers in sediments and fish species from the Murchison Bay of Lake Victoria, Uganda. Sci. Total Environ. 2014, 500-501, 1-10. [CrossRef] [PubMed]

4. Ruiz-Fernandez, A.C.; Ontiveros-Cuadras, J.F.; Sericano, J.L.; Sanchez-Cabeza, J.A.; Liong Wee Kwong, L.; Dunbar, R.B.; Mucciarone, D.A.; Perez-Bernal, L.H.; Paez-Osuna, F. Long-range atmospheric transport of persistent organic pollutants to remote lacustrine environments. Sci. Total Environ. 2014, 493, 505-520. [CrossRef] [PubMed]

5. De Wit, C.A. An overview of brominated flame retardants in the environment. Chemosphere 2002, 46, 583-624. [CrossRef]

6. Cincinelli, A.; Martellini, T.; Misuri, L.; Lanciotti, E.; Sweetman, A.; Laschi, S.; Palchetti, I. PBDEs in Italian sewage sludge and environmental risk of using sewage sludge for land application. Environ. Pollut. 2012, 161, 229-234. [CrossRef] [PubMed]

7. Alcock, R.E.; Sweetman, A.J.; Prevedouros, K.; Jones, K.C. Understanding levels and trends of BDE-47 in the UK and North America: An assessment of principal reservoirs and source inputs. Environ. Int. 2003, 29, 691-698. [CrossRef]

8. Darnerud, P.O.; Eriksen, G.S.; Johannesson, T.; Larsen, P.B.; Viluksela, M. Polybrominated diphenyl ethers: Occurrence, dietary exposure, and toxicology. Environ. Health Perspect. 2001, 109, 49-68. [CrossRef] [PubMed]

9. Gevao, B.; Muzaini, S.; Helaleh, M. Occurrence and concentrations of polybrominated diphenyl ethers in sewage sludge from three wastewater treatment plants in Kuwait. Chemosphere 2008, 71, 242-247. [CrossRef] [PubMed]

10. Song, W.; Ford, J.C.; Li, A.; Mills, W.J.; Buckley, D.R.; Rockne, K.J. Polybrominated diphenyl ethers in the sediments of the Great Lakes. 1. Lake Superior. Environ. Sci. Technol. 2004, 38, 3286-3293. [CrossRef] [PubMed]

11. Andersson, O.B.; Blomqvist, G. Polybrominated aromatic pollutants found in fish in Sweden. Chemosphere 1981, 10, 1051-1060. [CrossRef]

12. Nouira, T.; Risso, C.; Chouba, L.; Budzinski, H.; Boussetta, H. Polychlorinated biphenyls (PCBs) and Polybrominated Diphenyl Ethers (PBDEs) in surface sediments from Monastir Bay (Tunisia, Central Mediterranean): Occurrence, distribution and seasonal variations. Chemosphere 2013, 93, 487-493. [CrossRef] [PubMed]

13. Julshamn, K.; Duinker, A.; Berntssen, M.; Nilsen, B.M.; Frantzen, S.; Nedreaas, K.; Maage, A. A baseline study on levels of polychlorinated dibenzo- $p$-dioxins, polychlorinated dibenzofurans, non-ortho and mono-ortho PCBs, non-dioxin-like PCBs and polybrominated diphenyl ethers in Northeast Arctic cod (Gadus morhua) from different parts of the Barents Sea. Mar. Pollut. Bull. 2013, 75, 250-258. [PubMed]

14. Hites, R.A. Polybrominated diphenyl ethers in the environment and in people: A meta-analysis of concentrations. Environ. Sci. Technol. 2004, 38, 945-956. [CrossRef] [PubMed] 
15. Wong, F.; Robson, M.; Diamond, M.L.; Harrad, S.; Truong, J. Concentrations and chiral signatures of POs in soils and sediments: A comparative urban versus rural study in Canada and UK. Chemosphere 2009, 74, 404-411. [CrossRef] [PubMed]

16. Ter Schure, A.F.H.; Agrell, C.; Bokenstrand, A.; Sveder, J.; Larsson, P.; Zegers, B.N. Polybrominated diphenyl ethers at a solid waste incineration plant II: Atmospheric deposition. Atmos. Environ. 2004, 38, 5149-5155. [CrossRef]

17. Covaci, A.; Harrad, S.; Abdallah, M.A.; Ali, N.; Law, R.J.; Herzke, D.; de Wit, C.A. Novel brominated flame retardants: A review of their analysis, environmental fate and behaviour. Environ. Int. 2011, 37, 532-556. [CrossRef] [PubMed]

18. Binelli, A.; Provini, A. POPs in edible clams from different Italian and European markets and possible human health risk. Mar. Pollut. Bull. 2003, 46, 879-886. [PubMed]

19. Thomas, G.O.; Moss, S.E.W.; Asplund, L.; Hall, A.J. Absorption of decabromodiphenyl ether and other organohalogen chemicals by grey seals (Halichoerus. grypus). Environ. Pollut. 2005, 133, 581-586. [CrossRef] [PubMed]

20. Alava, J.J.; Ross, P.S.; Gobas, F.A.P.C. Food web bioaccumulation model for resident killer whales from the Northeastern Pacific Ocean as a tool for the derivation of PBDE-sediment quality guidelines. Arch. Environ. Contam. Toxicol. 2016, 70, 155-168. [CrossRef] [PubMed]

21. McDonald, T.A. A perspective on the potential health risks of PBDEs. Chemosphere 2002, 46, 745-755. [CrossRef]

22. Reinen, J.; Suter, M.J.; Vogeli, A.C.; Fernandez, M.F.; Kiviranta, H.; Eggen, R.I.; Vermeulen, N.P. Endocrine disrupting chemicals-Linking internal exposure to vitellogenin levels and ovotestis in Abramis brama from Dutch surface waters. Environ. Toxicol. Pharmacol. 2010, 30, 209-223. [CrossRef] [PubMed]

23. Mezcua, M.; Martinez-Uroz, M.A.; Gomez-Ramos, M.M.; Gomez, M.J.; Navas, J.M.; Fernandez-Alba, A.R. Analysis of synthetic endocrine-disrupting chemicals in food: A review. Talanta 2012, 100, 90-106. [CrossRef] [PubMed]

24. Branchi, I.; Capone, F.; Alleva, E.; Costa, L.G. Polybrominated diphenyl ethers: Neurobehavioral effects following developmental exposure. Neurotoxicology 2003, 24, 449-462. [CrossRef]

25. Darnerud, P.O. Toxic effects of brominated flame retardants in man and in wildlife. Environ. Int. 2003, 29, 841-853. [CrossRef]

26. Tseng, L.H.; Li, M.H.; Tsai, S.S.; Lee, C.W.; Pan, M.H.; Yao, W.J.; Hsu, P.C. Developmental exposure to decabromodiphenyl ether (PBDE 209): Effects on thyroid hormone and hepatic enzyme activity in male mouse offspring. Chemosphere 2008, 70, 640-647. [CrossRef]

27. Albina, M.L.; Alonso, V.; Linares, V.; Belles, M.; Sirvent, J.J.; Domingo, J.L.; Sanchez, D.J. Effects of exposure to BDE-99 on oxidative status of liver and kidney in adult rats. Toxicology 2010, 271, 51-56. [CrossRef] [PubMed]

28. Alonso, V.; Linares, V.; Belles, M.; Albina, M.L.; Pujol, A.; Domingo, J.L.; Sanchez, D.J. Effects of BDE-99 on hormone homeostasis and biochemical parameters in adult male rats. Food Chem. Toxicol. 2010, 48, 2206-2211. [CrossRef] [PubMed]

29. Belles, M.; Alonso, V.; Linares, V.; Albina, M.L.; Sirvent, J.J.; Domingo, J.L.; Sanchez, D.J. Behavioral effects and oxidative status in brain regions of adult rats exposed to BDE-99. Toxicol. Lett. 2010, 194, 1-7. [CrossRef] [PubMed]

30. Council of the European Communities (CEC). Directive 76/769/EEC of the European Parliament and of the Council of 27 July 1976 on the Approximation of the Laws, Regulations and Administrative Provisions of the Member States Relating to Restrictions on the Marketing and Use of Certain Dangerous Substances and Preparations; European Union: Brussels, Belgium, 1976.

31. Council of the European Communities (CEC). Directive 2003/11/EC of the European Parliament and of the Council of 6 February 2003 Amending for the 24th Time Council Directive 76/769/EEC Relating to Restrictions on the Marketing and Use of Certain Dangerous Substances and Preparations (Pentabromodiphenyl Ether, Octabromodiphenylether); European Union: Brussels, Belgium, 2003.

32. Court of Justice of the European Union (CJEU). Court Proceeding 2008/c116/02; European Union: Kirchberg, Luxembourg, 2008. 
33. Schuster, J.K.; Gioia, R.; Moeckel, C.; Agarwal, T.; Bucheli, T.D.; Breivik, K.; Steinnes, E.; Jones, K.C. Has the burden and distribution of PCBs and PBDEs changed in European background soils between 1998 and 2008? Implications for sources and processes. Environ. Sci. Technol. 2011, 45, 7291-7297. [CrossRef] [PubMed]

34. Olofsson, U.; Bignert, A.; Haglund, P. Time-trends of metals and organic contaminants in sewage sludge. Water Res. 2012, 46, 4841-4851. [CrossRef] [PubMed]

35. Munschy, C.; Heas-Moisan, K.; Tixier, C.; Olivier, N.; Gastineau, O.; Le Bayon, N.; Buchet, V. Dietary exposure of juvenile common sole (Solea solea L.) to polybrominated diphenyl ethers (PBDEs): Part 1. Bioaccumulation and elimination kinetics of individual congeners and their debrominated metabolites. Environ. Pollut. 2011, 159, 229-237. [CrossRef] [PubMed]

36. Echols, K.R.; Peterman, P.H.; Hinck, J.E.; Orazio, C.E. Polybrominated diphenyl ether metabolism in field collected fish from the Gila River, Arizona, USA-Levels, possible sources, and patterns. Chemosphere 2013, 90, 20-27. [CrossRef] [PubMed]

37. Josefsson, S.; Leonardsson, K.; Gunnarsson, J.S.; Wiberg, K. Bioturbation-driven release of buried PCBs and PBDEs from different depths in contaminated sediments. Environ. Sci. Technol. 2010, 44, 7456-7464. [CrossRef] [PubMed]

38. Zacs, D.; Rjabova, J.; Viksna, A.; Bartkevics, V. Method development for the simultaneous determination of polybrominated, polychlorinated, mixed polybrominated/chlorinated dibenzo- $p$-dioxins and dibenzofurans, polychlorinated biphenyls and polybrominated diphenyl ethers in fish. Chemosphere 2015, 118, 72-80. [CrossRef] [PubMed]

39. Hamm, S. Polybrominated diphenyl ethers in sewage sludge and effluents of sewage plants from a central region of Germany. Organohalog. Compd. 2004, 66, 1629-1634.

40. Fabrellas, B.; Larrazabali, D.; Martinez, M.A.; Eljarat, E.; Barcelo, D. Presence of polybrominated diphenylethers in Spanish sewage sludges: Important contribution of deca-BDE. Organohalog. Compd. 2004, $66,3755-3760$.

41. Chen, L.; Huang, Y.; Peng, X.; Xu, Z.; Zhang, S.; Ren, M.; Ye, Z.; Wang, X. PBDEs in sediments of the Beijiang River, China: Levels, distribution, and influence of total organic carbon. Chemosphere 2009, 76, $226-231$. [CrossRef] [PubMed]

42. Zhou, P.; Lin, K.; Zhou, X.; Zhang, W.; Huang, K.; Liu, L.; Guo, J.; Xu, F. Distribution of polybrominated diphenyl ethers in the surface sediments of the Taihu Lake, China. Chemosphere 2012, 88, 1375-1382. [CrossRef] [PubMed]

43. Shanmuganathan, D.; Megharaj, M.; Chen, Z.; Naidu, R. Polybrominated diphenyl ethers (PBDEs) in marine foodstuffs in Australia: Residue levels and contamination status of PBDEs. Mar. Pollut. Bull. 2011, 63, 154-159. [CrossRef] [PubMed]

44. Mackintosh, S.A.; Wallace, J.S.; Gross, M.S.; Navarro, D.D.; Pérez-Fuentetaja, A.; Alaee, M.; Montecastro, D.; Aga, D.S. Review on the occurrence and profiles of polybrominated diphenyl ethers in Philippines. Environ. Int. 2015, 85, 314-326. [CrossRef] [PubMed]

45. Ondarza, P.M.; Gonzalez, M.; Fillmann, G.; Miglioranza, K.S. Polybrominated diphenyl ethers and organochlorine compound levels in brown trout (Salmo trutta) from Andean Patagonia, Argentina. Chemosphere 2011, 83, 1597-1602. [CrossRef] [PubMed]

46. Bertelsen, S.L.; Hoffman, A.D.; Gallinat, C.A.; Elonen, C.M.; Nichols, J.W. Evaluation of log KOW and tissue lipid content as predictors of chemical partitioning to fish tissue. Environ. Toxicol. Chem. 1998, 17, 1447-1455. [CrossRef]

47. Knoth, W.; Mann, W.; Meyer, R.; Nebhuth, J. Polybrominated diphenyl ether in sewage sludge in Germany. Chemosphere 2007, 67, 1831-1837. [CrossRef] [PubMed]

48. Li, Y.; Zhou, Q.; Wang, Y.; Xie, X. Fate of tetrabromobisphenol A and hexabromocyclododecane brominated flame retardants in soil and uptake by plants. Chemosphere 2011, 82, 204-209. [CrossRef] [PubMed]

49. Zhao, M.; Zhang, S.; Wang, S.; Huang, H. Uptake, translocation, and debromination of polybrominated diphenyl ethers in maize. J. Environ. Sci. 2012, 24, 402-409. [CrossRef]

(C) 2017 by the authors; licensee MDPI, Basel, Switzerland. This article is an open access article distributed under the terms and conditions of the Creative Commons Attribution (CC BY) license (http:/ / creativecommons.org/licenses/by/4.0/). 